\title{
Corporate Social Responsibility : The Influence of Employee Engagement on Corporate Social Responsibility
}

\author{
Bayad Jamal Ali ${ }^{1}$, Govand Anwar ${ }^{2}$
}

\begin{abstract}
${ }^{1}$ Business Administration Department, Komar University of Science and Technology, Sulaimani 46001, Kurdistan Region - Iraq ${ }^{2}$ Department of Business Administration, College of Administration and Financial Sciences, Knowledge University, 44001 Erbil, Kurdistan Region, Iraq
\end{abstract}

Received: 18 Apr 2021; Received in revised form: 11 May 2021; Accepted: 09 Jun 2021

(C)2021 The Author(s). Published by TheShillonga. This is an open access article under the CC BY license (https://creativecommons.org/licenses/by/4.0/)

\begin{abstract}
Including more people being aware of corporate social responsibility, questions have arisen concerning whether there is a link between employee engagement and corporate social responsibility. Corporate Social Responsibility (CSR) is being considered as a significant component of a company's performance and activities, with the goal of increasing employee engagement. The goal of this study is to find out how employee engagement and corporate social responsibility are linked. The research was carried out in Erbil, Kurdistan, at vehicle dealerships. In total, 53 people took part in this study. According to the findings of this study, higher levels of corporate social responsibility can lead to higher levels of employee engagement, which supports the research hypothesis. The researchers recommended getting a larger sample size for similar studies in the future due to the study's restriction of a limited sample size.
\end{abstract}

Keywords-Corporate Social Responsibility, Employee Engagement, Erbil, Kurdistan.

\section{INTRODUCTION}

Corporate social responsibility (CSR) is a highly valued term that can be considered one of the key components in any organization's or company's success (Abdullah et al. 2021). CSR is a concept with numerous explanations and numerous economic (Ahmed et al. 2021), environmental, and social components (Akoi et al. 2021). Because CSR is seen as a key component of a company's success and activities (Ali \& Anwar, 2021), employee engagement will have an impact (Ali et al. 2021). Because employees play a significant influence in a company's success, there is a link between these two variables (Ali, 2014).

\section{LITERATURE REVIEW}

Corporate social responsibility is an essential idea that can be considered one of the aspects (Andavar et al. 2020) that determines a company's or organization's performance (Anwar \& Abd Zebari, 2015). CSR is a concept with a variety of definitions as well as economic (Anwar \& Abdullah, 2021), environmental, and social implications (Anwar \& Balcioglu, 2016). Businesses and government agencies are becoming more interested in this concept (Anwar \& Climis, 2017), which has sparked a spirited debate among experts (Anwar \& Ghafoor,2017). Increasing attention in the first place, as well as the efforts made by all organizations (Anwar \& Qadir, 2017), has led to the improvement of labor standards and anti-corruption measures (Anwar \& Shukur, 2015). The origins of the concept of corporate social responsibility as we know it today may be traced back a long way (Anwar \& Surarchith, 2015). A greater grasp of CSR is beneficial not only for comprehending the interaction between businesses and their stakeholders, but also for understanding and having a better notion of what business's role in development and contribution to society should be (Anwar, 2016). The concept of corporate social responsibility is not new or revolutionary (Anwar, 2017); the underlying tenet that a firm has a social obligation in addition to profit maximization objectives has a long history (Anwar, K., \& Louis, 2017). The concept and practice of corporate social responsibility (CSR) was alive and well between 1900 and 1960 (Aziz et al. 2021). Many major businesses in the first half of the twentieth century were accustomed with involving businesses in community issues and business (Demir et al. 2020). Employees are more conscious of the expansion of obligations and the firm's responsibility to society these days (Faraj et al. 2021), which means that 
employers are paying close attention to this issue, which should be handled seriously by managers and businesses (Hameed \& Anwar, 2018). The enthusiastic engagement of employees at all levels of the organization is the key to success in any corporation (Hamza et al. 2021). Engaging employees in corporate social responsibility is one aspect of having a responsible corporation. Because the workplace has an impact on employees, involving them in CSR will increase their performance while also boosting the organization's reputation (Ismael et al. 2021).

\section{Conceptual Framework Research Model}
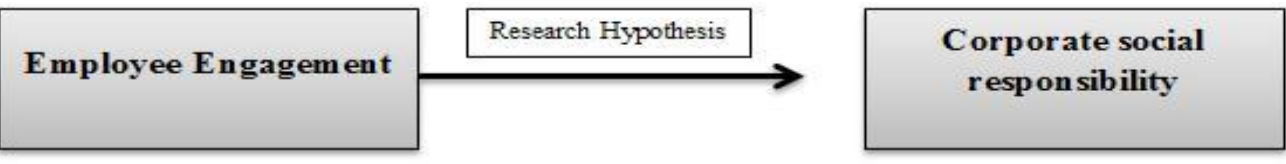

Fig.1: Research Model

\section{Research Hypothesis}

Higher employee engagement level can be achieved by higher level of corporate social responsibility.

\section{RESEARCH METHODOLOGY}

The purpose of this research is to examine the relationship between employee engagement and corporate social responsibility. The study was carried out among car dealerships in Erbil, Kurdistan. Total of 53 participants involved in this study. Five point likert scales was used in this study ranging from not important at all to very important.

\section{DATA ANALYSIS}

Table 1- Demographic Analysis

\begin{tabular}{|c|c|c|c|}
\hline Items & Scales & Frequency & Percent \\
\hline \multirow[t]{4}{*}{ Gender } & Male & & \\
\hline & & 30 & 55.6 \\
\hline & Female & & \\
\hline & & 24 & 44.4 \\
\hline \multirow{9}{*}{ Age } & $20-29$ & & \\
\hline & & 18 & 33.3 \\
\hline & & & \\
\hline & $30-39$ & & \\
\hline & & 17 & 31.5 \\
\hline & $40-49$ & & \\
\hline & & 13 & 24.1 \\
\hline & $50-59$ & & \\
\hline & & 6 & 11.1 \\
\hline \multirow[t]{3}{*}{ Education } & & & \\
\hline & Bachelor & 45 & 83.3 \\
\hline & Master & 9 & 16.7 \\
\hline \multirow[b]{2}{*}{ Experience } & Less than one & 9 & 16.7 \\
\hline & & & \\
\hline
\end{tabular}




\begin{tabular}{|c|c|c|c|}
\hline \multirow{2}{*}{} & $1-5$ & 26 & 48.1 \\
\cline { 2 - 4 } & $6-10$ & 17 & 31.5 \\
\cline { 2 - 4 } & 11 and over & 2 & 3.7 \\
\hline
\end{tabular}

The above table (1) demonstrates the participants demographic analysis participated in this research. In regard of the participants' gender; $55.6 \%$ of the participants were male while $44.4 \%$ of the participants were female. In regard of the participants' age; $33.3 \%$ of the participants were from 20-29 years old, $31.5 \%$ of the participants were $30-39$ years old, $24.1 \%$ of the participants were $30-39$ years old, $11.1 \%$ of the participants were from 50-59 years old. In regard of the participants ' level of education; $83 \%$ of the participants had bachelor degree and only $16.7 \%$ of the participants had Master degree. In regard of the participants' experience(s) $16.7 \%$ of the participants had less than one year of experience, $48.1 \%$ of the participants had $1-5$ years of the experiences, $31.5 \%$ of the participants had 6-10 years of the experiences and only $3.7 \%$ of the participants had 11 years and over of the experiences.

Table 2- Reliability Tests

\begin{tabular}{|c|r|c|}
\hline Items & Cronbach's Alpha & Number of Items \\
\hline Employee engagement & .849 & 10 \\
\hline CSR & .775 & 10 \\
\hline
\end{tabular}

The above table (2) shows the reliability test of 10 items for employee engagement and 10 items for corporate social responsibility. The Cronbach's Alpha for ten employee engagement's ten items $=.849$ which is greater than .6 this means that ten items used for employee engagement factor were reliable for this study and the Cronbach's Alpha for ten corporate social responsibility's ten items $=.775$ which is greater than .6 this means that ten items used for corporate social responsibility factor were reliable for this study.

Table 3-Correlations Analysis

\begin{tabular}{l|l|r|r|}
\hline Factors & Pearson Correlation & Engagement & CSR \\
\hline \multirow{4}{*}{ Employee Engagement } & Pearson Correlation & $.858^{* *}$ \\
\cline { 2 - 4 } & Sig. (2-tailed) & & .000 \\
\cline { 2 - 4 } & $\mathrm{N}$ & 54 & 54 \\
\hline \multirow{3}{*}{ CSR } & Pearson Correlation & .000 & 1 \\
\cline { 2 - 4 } & Sig. (2-tailed) & 54 & 54 \\
\cline { 2 - 4 } & $\mathrm{N}$ & & 54 \\
\hline
\end{tabular}

**. Correlation is significant at the 0.01 level (2-tailed).

The above table (3) shows the correlation analysis between employee engagement and corporate social responsibility. The value of Pearson Correlation $=.858^{* *}$ which is greater than 0.01 this means that there is a positive and strong correlation between employee engagement and corporate social responsibility. 


\begin{tabular}{|l|l|r|r|r|}
\hline Model & $\mathrm{R}$ & R Square & Adjusted R Square & Std. Error of the Estimate \\
\hline 1 & $.858^{\mathrm{a}}$ & .736 & .731 & .39631 \\
\hline
\end{tabular}

a. Predictors: (Constant), engagement

The above table (4) shows the value of $\mathrm{R}$ Square $=.736$ which means that $73 \%$ of the variables are explained in this study.

Table 5- ANOVA

\begin{tabular}{|rl|r|r|r|r|r|}
\hline Model & & Sum of Squares & df & Mean Square & F & Sig. \\
\hline \multirow{2}{*}{1} & Regression & 22.808 & 1 & 22.808 & 145.220 & $.000^{\mathrm{b}}$ \\
& Residual & 8.167 & 52 & .157 & & \\
& Total & 30.975 & 53 & & & \\
\hline
\end{tabular}

a. Dependent Variable: CSR

b. Predictors: (Constant), engagement

The above table (5) shows the value of $\mathrm{F}$ for both variables (employee engagement and corporate social responsibility) is $145.220>1$ which indicates there is a significant association between both variables.

Table 6- Coefficients

\begin{tabular}{|c|c|c|c|c|c|}
\hline \multirow[t]{2}{*}{ Model } & \multicolumn{2}{|c|}{ Unstandardized Coefficients } & \multirow{2}{*}{$\begin{array}{l}\text { Standardized } \\
\text { Coefficients } \\
\text { Beta }\end{array}$} & $\mathrm{t}$ & \multirow[t]{2}{*}{ Sig. } \\
\hline & $\mathrm{B}$ & Std. Error & & & \\
\hline (Constant) & .278 & .250 & & 1.115 & .270 \\
\hline engagement & .963 & .080 & .858 & 12.051 & .000 \\
\hline
\end{tabular}

\section{a. Dependent Variable: CSR}

The above table (6) shows the value of Beta=.858 which is greater than 0.01 this indicates that there is a positive relationship between employee engagement and corporate social responsibility.

\section{CONCLUSION}

The main aim of this research is to find out the relationship between employee engagement and corporate social responsibility in car dealership in Erbil, Kurdistan. A multiple regression analysis was used to analyze this research. Two different variables have been analyzed; employee engagement as independent variable and corporate social responsibility as dependent variable. The findings of this study revealed that higher employee engagement level could be attained by higher level of corporate social responsibility, accordingly the research hypothesis supported. The limitation of this study was the small sample size; the researchers recommended obtaining bigger sample size for similar studies in the future.

\section{REFERENCES}

[1] Top, C., \& Ali, B. J. (2021). Customer satisfaction in online meeting platforms: Impact of efficiency, fulfillment, system availability, and privacy. Amazonia Investiga, 10(38), 7081. https://doi.org/10.34069/AI/2021.38.02.7

[2] Demir, A., Maroof, L., Sabbah Khan, N.U. and Ali, B.J. (2020), "The role of E-service quality in shaping online meeting platforms: a case study from higher education sector", Journal of Applied Research in Higher Education. https://doi.org/10.1108/JARHE-08-2020-0253

[3] Ali, B, J. (2021). Impact of consumer animosity, boycott participation, boycott motivation, and product judgment on purchase readiness or aversion of Kurdish consumers in Iraq. 
Journal of Consumers Affaires; 1-20. https://doi.org/10.1111/joca. 12350

[4] Ali, B, J. (2020). Impact of COVID-19 on consumer buying behavior toward online shopping in Iraq. Economic studies journal. 18(42): 267-280. Retrieved from https://www.asjp.cerist.dz/en/article/134070

[5] Ali, B.J. (2021) Assessing (The impact) of advertisement on customer decision making: Evidence from an educational institution. Afak for sciences journal, 6(1): 425-439. Retrieved from https://www.asjp.cerist.dz/en/article/141056

[6] Ali, B.J. (2021) Consumer attitudes towards healthy and organic food in the Kurdistan region of Iraq. Management Science Letters. 11: 1-8. DOI: 10.5267/j.msl.2021.2.015

[7] Andavar, V., Ali, B.J., and Ali, S.A. (2020) Rainwater for Water Scarcity Management: An Experience of Woldia University (Ethiopia). Journal of Business, Economics and Environmental Studies, 10-(4): 29-34. DOI: 10.13106/jbees.2020.vol10.no4.29

[8] Faraj, K. M., Faeq, D. K., Abdulla, D. F., Ali, B. J., \& Sadq, Z. M. (2021). Total Quality Management And Hotel Employee Creative Performance: The Mediation Role Of Job Embeddedment. Journal of Contemporary Issues in Business and Government, 27(1), 3838-3855. http://dx.doi.org/10.47750/cibg.2021.27.01.001

[9] Ali, B. J. (2016). Iraq Stock Market and its Role in the Economy. Retrieved from https://www.amazon.com/IraqStock-Market-Role-Economy/dp/3659634271

[10] Ali, B. J. (2014). Brand Building in the Consumer Electronics Industry in Iraq. Retrieved from https://www.amazon.com/Brand-Building-ConsumerElectronics-Industry/dp/6200248699

[11] Ali, B. J., \& Anwar, G. (2021). Factors Influencing the Citizens' Acceptance of Electronic Government. International Journal of Engineering, Business and Management, $\quad 5(1), \quad 48-60$. https://doi.org/10.22161/ijebm.5.1.5

[12] Saleh, P. F., Ali, B. J., Akoi, S., Najmalddin, B., Ali, R. S., $\&$ Anwar, G. (2021). Factors affecting the Success of Female Entrepreneurs in Kurdistan. International journal of Engineering, Business and Management (IJEBM), 5.

[13] Ali, B. J., \& Anwar, G. (2021). The Effect of Marketing Culture Aspects of Healthcare Care on Marketing Creativity. International Journal of English Literature and Social Sciences, 6(2), 171-182. https://doi.org/10.22161/ijels.62.25

[14] Ali, B. J., \& Anwar, G. (2021). An Empirical Study of Employees' Motivation and its Influence Job Satisfaction. International Journal of Engineering, Business and Management, $\quad 5(2), \quad 21-30$. https://doi.org/10.22161/ijebm.5.2.3

[15] Ali, B. J., Saleh, P. F., Akoi, S., Abdulrahman, A. A., Muhamed, A. S., Noori, H. N., \& Anwar, G. (2021, May). Impact of Service Quality on the Customer Satisfaction: Case study at Online Meeting Platforms. In Ali, BJ, Saleh, Akoi, S., Abdulrahman, AA, Muhamed, AS, Noori, HN, Anwar, G.(2021). Impact of Service Quality on the Customer Satisfaction: Case study at Online Meeting Platforms.
International journal of Engineering, Business and Management (Vol. 5, No. 2, pp. 65-77).

[16] Ali, B. J., \& Anwar, G. (2021). The balanced scorecard's evolution as a strategic mechanism at banking sectors. International Journal of English Literature and Social Sciences, 6(1), 471-478. https://doi.org/10.22161/ijels.61.63

[17] Anwar, G., \& Abdullah, N. N. (2021). Inspiring future entrepreneurs: The effect of experiential learning on the entrepreneurial intention at higher education. International Journal of English Literature and Social Sciences, 6.

[18] Ali, B. J., \& Anwar, G. (2021). Measuring competitive intelligence Network and its role on Business Performance. International Journal of English Literature and Social Sciences, 6(2), 329-345. https://dx.doi.org/10.22161/ijels.62.50

[19] Anwar, G., \& Abdullah, N. N. (2021). The impact of Human resource management practice on Organizational performance. International journal of Engineering, Business and Management (IJEBM), 5.

[20] Abdullah, N. N., \& Anwar, G. (2021). An Empirical Analysis of Natural Gas as an Alternative Fuel for Internal Transportation. International Journal of English Literature and Social Sciences, 6(1).

[21] Ali, B. J., \& Anwar, G. (2021). A study of knowledge management alignment with production management: A study of carpet manufacture in Kurdistan region of Iraq. International Journal of English Literature and Social Sciences, 6(2), 346-360. https://dx.doi.org/10.22161/ijels.62.51

[22] Ali, B. J., \& Anwar, G. (2021). The mediation role of change management in employee development. International Journal of English Literature and Social Sciences, 6(2), 361374. https://dx.doi.org/10.22161/ijels.62.52

[23] Anwar, K., \& Louis, R. (2017). Factors Affecting Students' Anxiety in Language Learning: A Study of Private Universities in Erbil, Kurdistan. International Journal of Social Sciences \& Educational Studies, 4(3), 160.

[24] Ali, B. J., \& Anwar, G. (2021). Business strategy: The influence of Strategic Competitiveness on competitive advantage. International Journal of Electrical, Electronics and Computers, 6(2), 1-10. https://dx.doi.org/10.22161/eec.62.1

[25] Anwar, K. (2017). Leading Construction Project Teams: The Effectiveness of Transformational Leadership in Dynamic Work Environments in Kurdistan. International Journal of Advanced Engineering, Management and Science, 3(10), 239925.

[26] Ali, B. J., \& Anwar, G. (2021). Strategic leadership effectiveness and its influence on organizational effectiveness. International Journal of Electrical, Electronics and Computers, 6(2), 11-24. https://dx.doi.org/10.22161/eec.62.2

[27] Anwar, K., \& Qadir, G. H. (2017). A Study of the Relationship between Work Engagement and Job Satisfaction in Private Companies in Kurdistan. International Journal of Advanced Engineering, Management and Science, 3(12), 239944. 
[28] Ali, B. J., \& Anwar, G. (2021). Intellectual capital: A modern model to measure the value creation in a business. International journal of Engineering, Business and Management, 5(2), 31-43. https://dx.doi.org/10.22161/ijebm.5.2.4

[29] Ali, B. J., \& Anwar, G. (2021). Marketing Strategy: Pricing strategies and its influence on consumer purchasing decision. International journal of Rural Development, Environment and Health Research, 5(2), 26-39. https://dx.doi.org/10.22161/ijreh.5.2.4

[30] Anwar, K. (2017). Factors Affecting Stock Exchange Investment In Kurdistan. The International Journal of Accounting and Business Society, 25(1), 32-37.

[31] Ali, B. J., \& Anwar, G. (2021). Organization citizenship behaviour as a determining Factor in Business outcome. International journal of Rural Development, Environment and Health Research, 5(2), 17-25. https://dx.doi.org/10.22161/ijreh.5.2.3

[32] Anwar, K., \& Climis, R. (2017). Analyzing the relationship between types of advertisement and customer choice: a study of retailer stores in erbil. The International Journal of Accounting and Business Society, 25(2), 43-52.

[33] Talim, S.R., Ali, B.J., Top, C. (2021). Elaborating the Antecedents of Purchase Intentions in Second-Hand Car Industry: Case Study in Kurdistan Region of Iraq. Journal of Contemporary Issues in Business and Government, 27(3), 1526-1547. http://dx.doi.org/10.47750/cibg.2021.27.03.204

[34] Anwar, K., \& Ghafoor, C. (2017). Knowledge management and organizational performance: A study of private universities in Kurdistan. International Journal of Social Sciences \& Educational Studies, 4(2), 53.

[35] Ali, B. J., Saleh, Akoi, S., Abdulrahman, A. A., Muhamed, A. S., Noori, H. N., Anwar, G. (2021). Impact of Service Quality on the Customer Satisfaction: Case study at Online Meeting Platforms. International journal of Engineering, Business and Management, 5(2), 65-77. https://dx.doi.org/10.22161/ijebm.5.2.6

[36] Hameed, A. A., \& Anwar, K. (2018). Analyzing the Relationship between Intellectual Capital and Organizational Performance: A Study of Selected Private Banks in Kurdistan. International Journal of Social Sciences \& Educational Studies, 4(4), 39.

[37] Jamal Ali, B., Akoi, S., Fadel Saleh, P., \& Sardar, zhilwan. (2021). Factors Shaping Customer Satisfaction with Residential Flats: Evidence from Sulaymaniyah City. Black Sea Journal of Management and Marketing, 2(2), 1-12. https://doi.org/10.47299/bsjmm.v2i2.69

[38] Akoi, S., Jamal Ali, B., Fadel Saleh, P., Najmalddin, B., Sabah Mustafa, R., Rzgar Abdulmajid, M., \& Rebwar Hama, A. (2021). Elaborating the Characteristics that Affect Buyers in Online Shopping: The Case of Generation Z Girls in Kurdistan Region of Iraq. Black Sea Journal of Management

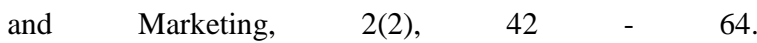
https://doi.org/10.47299/bsjmm.v2i2.74

[39] Anwar, K. (2017). The Role of Effective Leadership in Crisis Management: Study of Private Companies in Kurdistan. Qalaai Zanist Scientific Journal, 2(4), 326-338.
[40] Ahmed, S. Y., Ali, B. J., Top, C. (2021). Understanding the Impact of Trust, Perceived Risk, and Perceived Technology on the Online Shopping Intentions: Case Study in Kurdistan Region of Iraq. Journal of Contemporary Issues in Business and Government, 27(3), 2136-2153. http://dx.doi.org/10.47750/cibg.2021.27.03.264

[41] Anwar, K., \& Balcioglu, H. (2016). The relationship between transformational leadership characteristics and effectiveness: A case study of construction companies in Erbil. International Journal of Science Technology and Management, 5(2), 250-256.

[42] Sabir, B. Y., Othman, B .J., Gardi, B., Ismael, N. B., Hamza, P. A., Sorguli, S., Aziz, H. M., Ahmed, S. A., Ali, B. J., Anwar, G. (2021). Administrative Decentralization: The Transfer of Competency from The Ministry of Education to General Directorates. International Journal of Rural Development, Environment and Health Research, 5(3), 113. https://doi.org/10.22161/ijreh.5.3.1

[43] Abdullah, M. S., Toycan, M., \& Anwar, K. (2017). The cost readiness of implementing e-learning. CUSTOS E AGRONEGOCIO ON LINE, 13(2), 156-175.

[44] Ali, B. J., Anwar, G., Gardi, B., Othman, B. J., Aziz, H. M., Ahmed, S. A., Hamza, P. A., Ismael, N. B., Sorguli, S., Sabir, B. Y. (2021). Business Communication Strategies: Analysis of Internal Communication Processes. Journal of Humanities and Education Development, 3(3), 16-38. https://doi.org/10.22161/jhed.3.3.4

[45] Anwar, K. (2016). Comparison between cost leadership and differentiation strategy in agricultural businesses. Custos E Agronegocio on Line, 12(2), 212-231.

[46] Ali, B. J., Gardi, B., Othman, B. J., Ismael, N. B., Sorguli, S., Sabir, B. Y., Ahmed, S. A., Hamza, P. A., Aziz, H. M., Anwar, G. (2021). Educational system: The policy of Educational system in Kurdistan Region in public Kindergarten. International Journal of English Literature and Social Sciences, 6(3), 062-071. https://doi.org/10.22161/ijels.63.10

[47] Anwar, K. (2017). Analyzing the conceptual model of service quality and its relationship with guests'satisfaction: a study of hotels in erbil. The International Journal of Accounting and Business Society, 25(2), 1-16.

[48] Aziz, H. M., Othman, B. J., Gardi, B., Ahmed, S. A., Sabir, B. Y., Ismael, N. B., Hamza, P. A., Sorguli, S., Ali, B. J., Anwar, G. (2021). Employee Commitment: The Relationship between Employee Commitment And Job Satisfaction. Journal of Humanities and Education Development, 3(3), 54-66. https://doi.org/10.22161/jhed.3.3.6

[49] Anwar, G., \& Shukur, I. (2015). The Impact of Service Quality Dimensions on Students' Satisfaction. International Journal of Social Sciences \& Educational Studies, 76.

[50] Ali, B. J., Gardi, B., Othman, B. J., Ahmed, S. A., Ismael, N. B., Hamza, P. A., Aziz, H. M., Sabir, B. Y., Anwar, G. (2021). Hotel Service Quality: The Impact of Service Quality on Customer Satisfaction in Hospitality. International Journal of Engineering, Business and Management, 5(3), 14-28. https://doi.org/10.22161/ijebm.5.3.2 
[51] Anwar, G., \& Surarchith, N. K. (2015). Factors Affecting Shoppers' Behavior in Erbil, Kurdistan-Iraq. International Journal of Social Sciences \& Educational Studies, 1(4), 10.

[52] Sorguli, S., Gardi, B., Othman, B.J., Aziz, H. M., Ahmed, S. A., Sabir, B. Y., Ismael, N. B., Hamza, P. A., Ali, B. J., Anwar, G. (2021) Innovation: Knowledge Management in the Innovating Industries, 6(3), 10-23. https://dx.doi.org/10.22161/eec.63.2

[53] Anwar, G., \& Abd Zebari, B. (2015). The Relationship between Employee Engagement and Corporate Social Responsibility: A Case Study of Car Dealership in Erbil, Kurdistan. International Journal of Social Sciences \& Educational Studies, 2(2), 45.

[54] Hamza, P. A., Othman, B. J., Gardi, B., Sorguli, S., Aziz, H. M., Ahmed, S. A., Sabir, B. Y., Ismael, N. B., Ali, B. J., Anwar, G. (2021). Recruitment and Selection: The Relationship between Recruitment and Selection with Organizational Performance. International Journal of Engineering, Business and Management, 5(3), 1-13. https://doi.org/10.22161/ijebm.5.3.1

[55] Anwar, G., \& Shukur, I. (2015). the impact of recruitment and selection on job satisfaction: Evidence from private school in Erbil. International Journal of Social Sciences \& Educational Studies, 1(3), 4-13.

[56] Ali, B. J., Gardi, B., Othman, B. J., Sabir, B. Y., Sorguli, S., Ismael, N. B., Hamza, P.A., Aziz, H. M., Ahmed, A. A., Anwar, G. (2021). The Role of Shopping Malls on Kurdistan Regional Government's Economy. Journal of Humanities and Education Development, 3(3), 39-53. https://doi.org/10.22161/jhed.3.3.5

[57] Anwar, G., \& Shukur, I. (2015). Job satisfaction and employee turnover intention: A case study of private hospital in Erbil. International Journal of Social Sciences \& Educational Studies, 2(1), 73.

[58] Ahmed, S. A., Othman, B. J., Gardi, B., Sabir, B. Y., Ismael, N. B., Hamza, P. A., Sorguli, S., Aziz, H. M., Ali, B. J., Anwar, G. (2021). Students' Attitudes towards Learning English in the Kurdistan region of Iraq. International Journal of English Literature and Social Sciences, 6(3), 072-087. https://doi.org/10.22161/ijels.63.11

[59] Anwar, G., \& Shukur, I. (2015). The Impact of Training and Development on Job Satisfaction: A Case Study of Private Banks in Erbil. International Journal of Social Sciences \& Educational Studies, 2(1), 65.

[60] Ismael, N. B., Othman, B. J., Gardi, B., Hamza, P. A., Sorguli, S., Aziz, H. M., Ahmed, S. A., Sabir, B. Y., Ali, B. J., Anwar, G. (2021). The Role of Training and Development on Organizational effectiveness. International Journal of Engineering, Business and Management, 5(3), 15-24. https://doi.org/10.22161/ijebm.5.3.3 